\title{
The genus Anthelephila (Coleoptera: Anthicidae)
}

\author{
ZBYNĚK KEJVAL
}

Muzeum Chodska, CZ-344 01 Domažlice, Czech Republic; e-mail: kejval@cmail.cz

Key words. Taxonomy, redescription, new synonymy, lectotype designation, Coleoptera, Anthicidae, Anthelephila

\begin{abstract}
The genus Anthelephila Hope, 1833 and its type species, Anthelephila cyanea Hope, 1833, are redescribed. Based on examination of the type material, the following new synonymy is proposed, Anthelephila Hope, 1833 (=Formicoma Motschoulsky, 1845 syn. n.) and $A$. cyanea Hope, 1833 (= Notoxus caeruleus Thunberg, 1787 syn. n.). Five genus-group names are regarded as unjustified emendations and are placed as synonyms: Anthelephila Hope, 1833 (=Anthelephilus LaFerté-Sénectère, 1849; Formicosoma Motschoulsky, 1845; Myrmecosoma Mannerheim, 1846; Formicomus LaFerté-Sénectère, 1849; Orthauchen KrekichStrassoldo, 1925 syn. n.). A lectotype is designated for Anthelephila cyanea Hope, 1833.
\end{abstract}

\section{INTRODUCTION}

There are two closely related genera currently placed in the Formicomini: Anthelephilus LaFerté-Sénectère, 1849, comprising about 20 species, and Formicomus LaFertéSénectère, 1849 comprising more than 350 species. Unfortunately, the present nomenclatorical status of both these names is in serious contradiction with the ICZN (1999) rules, since they were knowingly and unjustifiedly proposed by Hope (1840) and LaFerté-Sénectère (1849a, b) to replace the older names Anthelephila Hope, 1833 and Formicoma Motschoulsky, 1845, with new spellings for these two genera accepted by nearly all subsequent authors.

The present paper is aimed to solve the above mentioned problem, and to provide a redescription of the genus Anthelephila Hope and its type species. Furthermore, brief remarks are made upon the general topics of biology, geographic distribution, and position of Anthelephila within the subfamily Anthicinae.

\section{MATERIAL AND METHODS}

Specimens were examined with a stereoscopic microscope using diffused lighting, and illustrations were made using an ocular microgrid. Morphological measurements were taken using the ocular micrometer. Male and female genitalia were illustrated after having been cleared by boiling in $10 \% \mathrm{KOH}$ solution.

Author's comments on the type material are found in square brackets. Exact label data are quoted for the type specimens only. Separate labels are indicated by slashes (1). The publication date of the papers by LaFerté-Sénectère follows Chandler (2000).

\section{DEPOSITORIES}

BMNH - The Natural History Museum, London, England.

MNHB - Museum für Naturkunde der HumboldtUniversität, Berlin, Germany.

OXUM - Hope Entomological Collections, Oxford, England.
UZIU - Uppsala University, Zoological Museum, Uppsala, Sweden.

CKD - collection Zbyněk Kejval, Domažlice, Czech Republic.

CUP - collection Gerhard Uhmann, Pressath, Germany.

DSC - collection Donald S. Chandler, Durham, New Hampshire, U. S. A.

\section{TAXONOMY}

\section{Taxonomic history of the treated generic names}

Anthelephila, Anthelephilus. The genus Anthelephila was originally established by F. W. Hope as a subgenus of Anthicus Paykull, 1798. The description was initially read at the meeting of the Zoological Society in London on May 28th 1833, and then published as a report of this meeting in an abbreviated format (comprising only more important characters of the genera and species described) in July of the same year in the Proceedings of Zoological Society of London (Hope, 1833). The full description was published the next year (Hope, 1834) in the Transactions of the Zoological Society of London. Since the description in the Proceedings is clearly attributed to Hope and lists several characters for recognition of the genus Anthelephila and its type species, Anthicus cyaneus Hope, it is regarded as the original description (cf. Sherborn, 1928; Neave, 1939). Saunders (1834) added another two species and was the first to treat Anthelephila as a genus, without providing any comments on his rationale for this elevation. A change in gender to Anthelephilus was first used, without comments, by Hope (1840) to replace Anthelephila. Although he used Anthelephilus in combination with Hope's authorship, LaFerté-Sénectère (1849a, c) was apparently quite unaware of the preceding paper by Hope, and proposed more formally the same emendation, along with a generic description.

According to the ICZN (1999), Anthelephilus is regarded as unjustified emendation of Anthelephila. After 1899, Anthelephila was used as valid name by KrekichStrassoldo (1931), Sakai (1989) and Lafer (1996). In 
addition, Krekich-Strassoldo (1928) described Anthelephilus curtulus, but he noted in the same paper that this species must be named Anthelephila. Anthelephilus was used as valid name within the last 50 years by the following seven authors (Schütz is the maiden name of Claudia Hemp): Bonadona (1974, 1978, 1984, 1989), Hemp (1994), Hille (1953), Nomura (1962), Pic (1956), Schütz (1989), Telnov (1997, 1998a, 1998b, 1999), Uhmann (1976, 1978, 1980, 1981, 1983a, 1985a, 1986, 1987a, 1988, 1989, 1990a, 1990b, 1990c, 1990d, 1994a 1994b, 1996). As a consequence, it is not possible to apply regulation of the Article 23.9.2 of the ICZN (1999) and Anthelephilus must be regarded as junior synonym of Anthelephila.

Formicoma, Formicosoma, Formicomus. The genus Formicoma was established without description by Motschoulsky (1845a) to accommodate three Palaearctic species of Anthicus Paykull, 1798. Subsequently, Motschoulsky (1845b) emended Formicoma to Formicosoma in a list of corrections to the preceding paper.

The name Formicomus was established by LaFertéSénectère to replace Formicoma. This fact is evident from the following statement: “...depuis, ayant appris que M.V. Motschoulsky avait également séparé ces insectes des Anthicus dans le catalogue de sa collection actuellement sous presse, et qu'il leur avait donné le nom Formicoma, nous avons cru devoir, pour simplifier la nomenclature, adopter le nom de M. Motschoulsky, en lui donnant une terminaison masculine" (footnote in LaFerté-Sénectère, 1849b: 2).

According to the ICZN (1999), both Formicosoma and Formicomus are unjustified emendations of Formicoma. On the other hand, Formicoma was used later as a valid name only by Kolenati (1846) and Motschoulsky (1849), and the youngest name Formicomus is undoubtedly in prevailing usage and could thus be conserved (ICZN, 1999: Article 23.9.1.1-2). This action, however, would be unnecessary for the reasons described below.

Myrmecosoma. The name Myrmecosoma was proposed by Mannerheim (1846) to replace Formicosoma, since he believed the latter name to be incorrectly composed. It was used later only by Truqui (1855) and usually has been treated as synonym of Formicomus. According to the ICZN (1999), it is regarded as unjustified emendation of Formicosoma.

Orthauchen. The subgenus Orthauchen was established by Krekich-Strassoldo (1925) to accomodate the species of Formicomus with long neck smoothly merging with head. It was recently synonymized with the nominotypical subgenus by Kejval (2000).

Carteromerus. Pic (1911) listed Carteromerus as synonym of Formicomus with the following data: "Carteromerus Laf. (Monogr. 1848, p. 71, nota 1)." According to the respective note (pages 2,71) in LaFerté-Sénectère $(1849 \mathrm{~b}, \mathrm{c})$, Carteromerus is the original name LaFertéSénectère meant to use before he decided to emend Motschoulsky's Formicoma. It occurs on the original labels in the LaFerté-Sénectère's collection, however it was never officially established since there were no explicitly included species, and he never used it as a valid name. Consequently, it is herein regarded as an unavailable name.

\section{Comments on the newly proposed synonymy}

The only character traditionally used to separate the genera Formicomus and Anthelephilus is the absence of hind membranous wings in the latter genus, which is related to the obsolete elytral humeri, and sometimes also to the truncate elytral apices. This difference was first noted by LaFerté-Sénectère; although he had not seen the type specimen of Anthelephila, he assumed its aptery solely from a copy (Fig. 8) of the original habitus illustration (Fig. 9) provided by Chevrolat (LaFerté-Sénectère, 1849a: 1). However, as was already stressed by some early workers (Lacordaire, 1859; King, 1869), there is no supporting evidence for this division. The reduction of hind wings is well known in numerous genera of Anthicidae, and their tendency toward reduction has been observed in a group of closely related species of Formicomus (Kejval, 2000). The most widely known species treated under the name Anthelephilus (A. ruficollis Saunders, 1834) appears to vary in this character as I have seen fully winged, brachypterous, and apterous specimens. Finally, examination of the type material has shown that the type species of the genus Anthelephila is not apterous (see the redescription of $A$. cyanea below).

Motschoulsky (1845a) designated "Anth. pedestris F." as the type species of Formicoma. Why Motschoulsky and Dejean (1837) attributed this species to Fabricius is not clear. It is evident from the data given by Fabricius (1801), that he just proposed one new combination for the species described as Carabus pedestris by Rossi (1790), and accordingly Anthicus pedestris is not listed as a Fabrician species by Zimsen (1964). The major part of the collection of P. Rossi is now deposited in MNHB as a part of the so called "Historical collection," and present there is the series labelled "Pedestris R.* [R. = Rossi, * = type material], Anthicus. pedestris Fab., N. thoracicus Pz.," comprising specimens of various origin, including the type(s) of Carabus pedestris Rossi, 1790. Having examined the whole series, I found it homogeneous and belonging to Formicomus pedestris (Rossi, 1790) in its present sense, which is a well known species clearly congeneric with Anthelephila cyanea. Considering these facts, Formicoma, Formicosoma, Myrmecosoma and Formicomus are all regarded as junior synonyms of Anthelephila.

\section{Genus Anthelephila Hope, 1833 \\ Anthicus subg. Anthelephila Hope, 1833: 63.}

Type species. Anthicus (Anthelephila) cyaneus Hope, 1833; fixed by monotypy.

Anthelephilus LaFerté-Sénectère, $1849 \mathrm{a}: 1$, syn. n. Antelephilus; Pic, 1901: 249. Subsequent misspelling of Anthelephilus.

Antelophilus; Pic, 1899: 758. Subsequent misspelling of Anthelephilus. 
Anthlephilus; Krekich-Strassoldo, 1929: 475. Subsequent misspelling of Anthelephilus.

Formicoma Motschoulsky, 1845a: 83, syn. n.

Type species. Carabus pedestris Rossi, 1790 (as Anthicus pedestris); fixed by original designation.

Formicosoma Motschoulsky, 1845b: unnumbered erratum page, syn. $\mathbf{n}$.

Myrmecosoma Mannerheim, 1846: 227, syn. n.

Formicomus LaFerté-Sénectère, 1849b: 1, syn. n.

Orthauchen Krekich-Strassoldo, 1925: 516, syn. n.

Type species. Formicomus aestimabilis Krekich-Strassoldo, 1919; fixed by subsequent designation by Kejval (2000).

Carteromerus [nomen nudum].

Diagnosis. Frontoclypeal sulcus fine but distinct. Pronotum with distinct apical flanged rim (collar), more or less prominent lateral antebasal impression in posterior half and with basal margin distinctly bordered dorsally by a thin, well defined sulcus originating at lateral foveae. Mesosternum triangular, anterior angle of mesosternum distant from anterior margin of mesothorax due to the medially broadly joined mesepisterna (Figs 1, 6), lateral margins either moderately arcuate or straight, intercoxal process fully separating mesocoxae; lateral margins of mesepisterna simply connected (not raised above level of) with mesepimera (Figs 2, 11), bare, without distinct fringe of setae. Mesothoracic gland conspicuously large, differentiated into paired canal and reservoir and its opening sunk into mesothorax (Hemp, 1994). Mesoscutellum longitudinally triangular, tapering posteriorly (Fig. 21). Metendosternite with narrow arms and obsolete ventro-lateral projections (lamina) (Fig. 12). Elytra in males lacking apical notches; sutural striae very vaguely indicated in apical third. Antennal insertion exposed and clearly visible, sockets sometimes slightly hidden by moderately raised lateral margin of frons in dorsal view. All femora distinctly clavate, metafemora simply shaped; all tibiae with two well developed apical spurs (most prominent on metatibiae). Abdominal sternum III without foveae immediately behind metacoxae, its intercoxal process widely, somewhat irregularly rounded apically and incompletely bordered in ventral view (Figs 3, 4); male abdominal segment VIII modified, sternite with a pair of posteriorly projecting prongs; male sternite IX (spiculum) formed by comparatively fine, fibre-like apodeme, bifurcate posteriorly, Y-shaped (Fig. 28). Male aedeagus less sclerotized, tegmen clearly divided into the apical portion (formed by fused parameres) and basalpiece; median lobe strengthened by simple, rod-like, sclerotized apodeme, gonopore (of rather uniform morphology) situated at level or shortly behind basal margin of tegmen (Fig. 29). Female ovipositor (Fig. 19) with well developed coxites and styli.

Sexual dimorphism. Adults of most species of Anthelephila show rather distinct sexual dimorphism. Males are usually of smaller size and exhibit a more slender bodyform than females, sometimes have slightly longer antennae, and display a number of conspicuous secondary sexual characters: front legs almost exclusively modified, with variously shaped processes, protuberances (very rarely present also on meso- or metatibiae); metasternum and abdominal sterna III-VI often with longitudinal ribs, protrusions or protuberances, impressions, densely punctured and setose patches; abdominal sternum VII with posterior margin variously shaped (very rarely simple), often more or less emarginate, often with median process of various form and length; sternite VIII always modified and mostly of rather complicated morphology, its paired prongs armed with various processes, lobes, clustered setae etc.; metatibiae and metatarsi sometimes with longer, bristle-like setae.

Females are generally more simple in appearance: legs, metasternum and abdominal sterna III-VI always simple; sternum and tergum VII predominantly simply shaped, rarely somewhat prolonged and more tapering, sometimes truncate or notched apically; segment VIII weakly sclerotized, composed of fine simple sclerites, more or less conspicuously setose along posterior margin. Sometimes, females may differ from males by the modified mesosternum (see Figs 92-102 in Kejval, 2000), but in general they very rarely possess a modifications not found in their respective males, e.g. the prolonged and tapering elytral apices (few Oriental species) or the densely punctured and setose patches on the pronotum ( $A$. picta Kejval, 2002).

Immature stages. The first instar of larva of Anthelephila pedestris (Rossi, 1790) was described by Schütz (1989).

Biology. Anthelephila appears to be relatively thermophilous, with the majority of species occuring in the tropics of Africa and southeast Asia, and only few species penetrating more northwards into the Eurosiberian subregion. Its members inhabit both open and forested habitats at elevations ranging from sea level up to $3500 \mathrm{~m}$ (in the Himalaya Mts.). They are mostly collected by sweeping vegetation or beating foliage along trails, or at the margins of clearings.

Both larvae and adults of Anthelephila are apparently scavengers and opportunistic predators, feeding on organic debris and small or weakened invertebrates, as it is typical of most other genera of Anthicidae (Werner \& Chandler, 1995). Mycophagy was observed by Hemp et al. (1997) for adults of two species in Tanzania.

At this time fourteen species of Anthelephila are known to be canthariphilous, that is they are known to to be attracted to the terpenoid cantharidin (Hemp \& Dettner, 2001). This substance serves as a mating attractant, and perhaps functions as an aggregation pheromone. In addition, as a toxic component of haemolymph, it provides protection for both adults and immature stages (Hemp et al., 1997, Hemp \& Dettner, 1997). Based on field observations and chemical analyses (Hemp \& Dettner, 1997), adults of Anthelephila are effectively protected by iridoids secreted by the mesothoracic glands.

Species of Anthelephila may resemble ants in appearance and pattern of movement, as have been noted in species of other groups of anthicids (Werner \& Chandler, 1995). Various species of Anthelephila (as Formicomus) 
have been found running together with ants (Hemp \& Dettner, 1997; Hingston, 1925; Wasmann, 1898), even near their nests, but only a few species may be potentially regarded as myrmecophilous (Wasmann, 1898).

Distribution. Considering the herein proposed synonymy, Anthelephila contains nearly 400 species distributed in the Palaearctic, Afrotropical, Oriental and Australian regions. It is absent from the New World; all species of Formicomus described from Chile belong to different genera (Werner, 1966, 1974). The genus is extremely diverse in southeast Asia, but I know of only a few species that are east of Wallace's line and occuring in Australia. All Australian species belonging to Anthelephila (about half of known Australian "Formicomus") show a clear relationship to some of their Oriental congeners, and they are most frequent in the humid northern and northwestern regions of Australia. The species with dentate metafemora, which predominantly inhabit the southern arid regions of Australia, belong in my opinion to the genus Chileanthicus Werner, 1966 (Kejval, in prep.). The only species known from New Caledonia, F. austrocaledonicus Montrouzier, 1854, belongs to a different, unrelated genus.

Relationships. Based on male characters, Bonadona (1974) established the tribe Formicomini for the genera Formicomus, Anthelephilus, Stenidius LaFerté-Sénectère, 1847 and Andrahomanus Pic, 1903, which all have sternite VIII of the males strongly modified. This tribe was both omitted (Uhmann, 1976) and accepted (Bucciarelli, 1980; Hemp, 1994) by subsequent authors. Although I am not quite convinced of the status of the tribe Formicomini, the following three characters may represent synapomorphies suggesting (in combination) the placement of Anthelephila with Stenidius, Andrahomanus and Chileanthicus: i) mesepisterna simply connected with mesepimera, their margins not raised and bare (Fig. 11); ii) the intercoxal process of abdominal sternum III widely rounded to subtruncate and incompletely bordered (Fig. 4); iii) male sternite VIII modified, with distinct posteriorly projecting prongs.

In the other genera of Anthicinae that I have examined the postero-lateral margins of mesepisterna were found to be completely (as in Fig. 20) or at least partly raised in the posterior half above the more or less recessed anterior portion of mesepimera. Similarly, I failed to find a species from any of the other genera sharing both of the following two characters. The examples where one of these characters occurs represent, in my opinion, convergent evolution rather than evidence of relationship. As far as I know, only males of Acanthinus LaFerté-Sénectère, 1849 and some Vacusus Casey, 1895 possess forms of sternite VIII that may resemble the structures developed as in the above mentioned genera (see for example Fig. 43 by Werner 1970). However, the intercoxal process of abdominal sternum III in these two genera is always acutely angulate apically and with the margins completely bordered; representatives of all major groups of the large genus Acanthinus were examined, including the Australian species (D.S. Chandler, pers. comm.). On the other hand, the comparatively wide, apically rounded intercoxal process of abdominal sternum III occurs in various genera of Anthicinae and it can be even extremely finely, indis- tinctly bordered apically (although very rarely). However, sternite VIII in males of the respective species was always found to be formed by a simple flattened sclerite, with the posterior margin at most emarginate to incised medially. The genera Phalantias Heberdey, 1936 from South India and Sri Lanka, and Falsoformicomus Pic, 1948 from Madagascar, were tentatively included in the Formicomini by Hemp (1994), but share neither of the mentioned synapomorphies and exhibit other striking differences (see Bonadona, 1958, 1982).

Within the group of related genera, Anthelephila differs by the following major characters: anterior angle of mesosternum distant from anterior margin of mesothorax due to the medially broadly joined mesepisterna (angle situated at least very near this margin in the remaining three genera); all femora clavate (meso- and metafemora narrow in Stenidius); ovipositor with well developed styli (ovipositor without apparent styli in Chileanthicus and Andrahomanus).

\section{Anthelephila cyanea Hope, 1833}

(Figs 1-19, 21-30)

Anthicus (Anthelephila) cyaneus Hope, 1833: 63.

Notoxus caeruleus Thunberg, 1787: 45, syn. n.

\section{Redescription.}

Body. Total length. 3.2-4.1 mm (lectotype $3.9 \mathrm{~mm}$ ).

Colouration. Black, head and pronotum with very slight bluish tinge, elytra with very distinct blue metallic reflection.

Head. Head 1.2 times as long as wide, moderately widely rounded posteriorly in dorsal view; tempora arcuately narrowing towards base; hind temporal angles rounded; base distinctly differentiated from short neck; dorsal face of head evenly vaulted; frontal region slightly, longitudinally impressed on each side along slightly raised lateral margins. Dorsal surface distinctly, largely simply punctured; interspaces among punctures much wider than their diameter, without traces of corrugation, mostly smooth, finely punctured postero-laterally; pubescence rather short, composed of decumbent setae and few, sparsely scattered, suberect to erect setae.

Antennae moderately long, distinctly exceeding elytral humeri, distinctly enlarged and flattened distally; antennomere I thick, 1.7 times as long as wide; antennomere II shortest, 1.2 times as long as wide; antennomeres III-VII each about twice as long as wide; antennomere $\mathrm{X} 1.2$ times as long as wide; antennomere XI twice as long as wide, slightly narrowed at about midlength and bluntly pointed apically. Antennomeres mostly sparsely setose, with several longer erect setae towards apices; distal antennomeres VIII-XI much more densely and shortly setose, with erect setae less conspicuous.

Thorax. Pronotum 1.5 times as long as wide, as long as and distinctly narrower than head including eyes, widest before midlength, distinctly constricted (impressed laterally) in posterior half; anterior portion somewhat angulately shaped (Figs 5,6), with rounded edge and distinct incision laterally to collar, surface behind collar flattened to slightly concave dorsally and dorso-laterally. Dorsal 

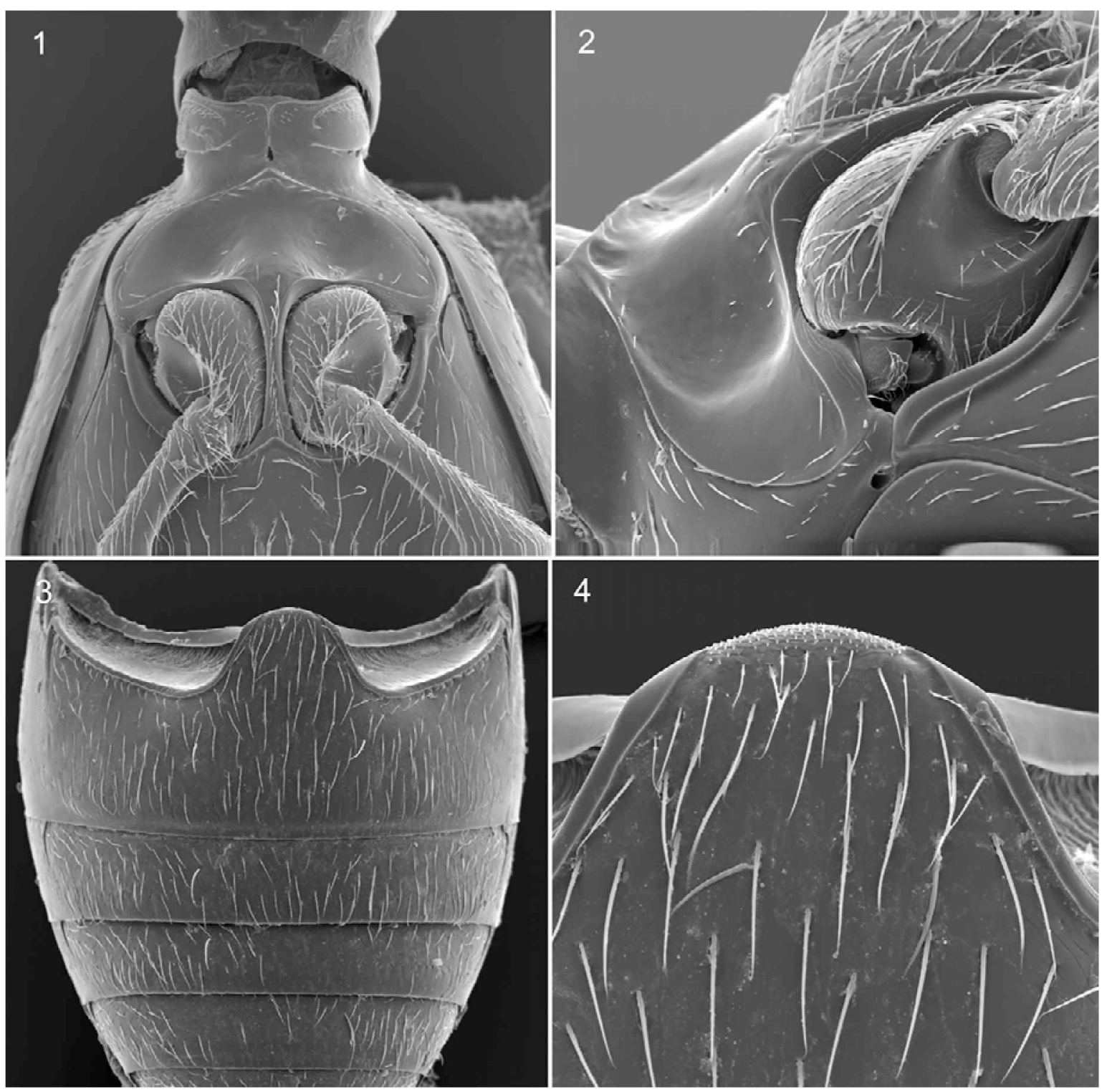

Figs 1-4. Anthelephila cyanea (female, SEM photographs). 1 - mesothorax, ventral view $(100 \times) ; 2$ - mesosternum, ventro-lateral view $(200 \times)$; 3 - abdomen, ventral view $(90 \times) ; 4-$ intercoxal process of abdominal sternum III, ventral view $(180 \times)$.

punctation of pronotum similar to that of head, slightly denser mid-dorsally; antero-lateral sides with only few, very fine punctures dorso-laterally, largely smooth and glossy, bottom of latero-basal impressions shortly, finely wrinkled and small vaulted area situated posterior to impressions finely punctured.

Mesosternum (Figs 1,2) modified, equal in both sexes; distinctly impressed along antero-lateral margins and with rather distinct, rounded postero-median bulge situated at level of anterior margins of mesocoxae; paired anterolateral impressions shallowly interconnected medially and becoming gradually more prominent laterad; surface largely smooth and glossy, only the intercoxal process more distinctly punctured and setose. Metasternum simple in both sexes, only shallowly impressed posteromedially.

Elytra 1.5 times as long as wide, less elongate, rather convex, moderately transversely impressed dorsally in post-scutellar area in basal third, somewhat subtruncate apically; humeri less protruding but distinct. Surface rather glossy; punctation double, setigerous punctures sparser (especially in basal third) than on dorsal side of head and pronotum, and finer, except for few coarse punctures scattered in post-scutellar area and bearing longer tactile setae, interspaces among setigerous punctures very finely sparsely punctured, asetose; pubescence rather short, at most slightly longer than on head and pronotum, becoming denser and shorter towards elytral apices, composed of subdecumbent to nearly appressed short setae and slightly longer erect setae, with some distinctly longer suberect to erect setae in post-scutellar area. Membranous wings well developed (Fig. 16)

Legs. Penultimate tarsomere of all tarsi flattened distally, with apical margin slightly emarginate and with terminal tarsomere articulated on its dorsal side, distinctly before apex. Male front legs modified (Fig. 22); pro- 


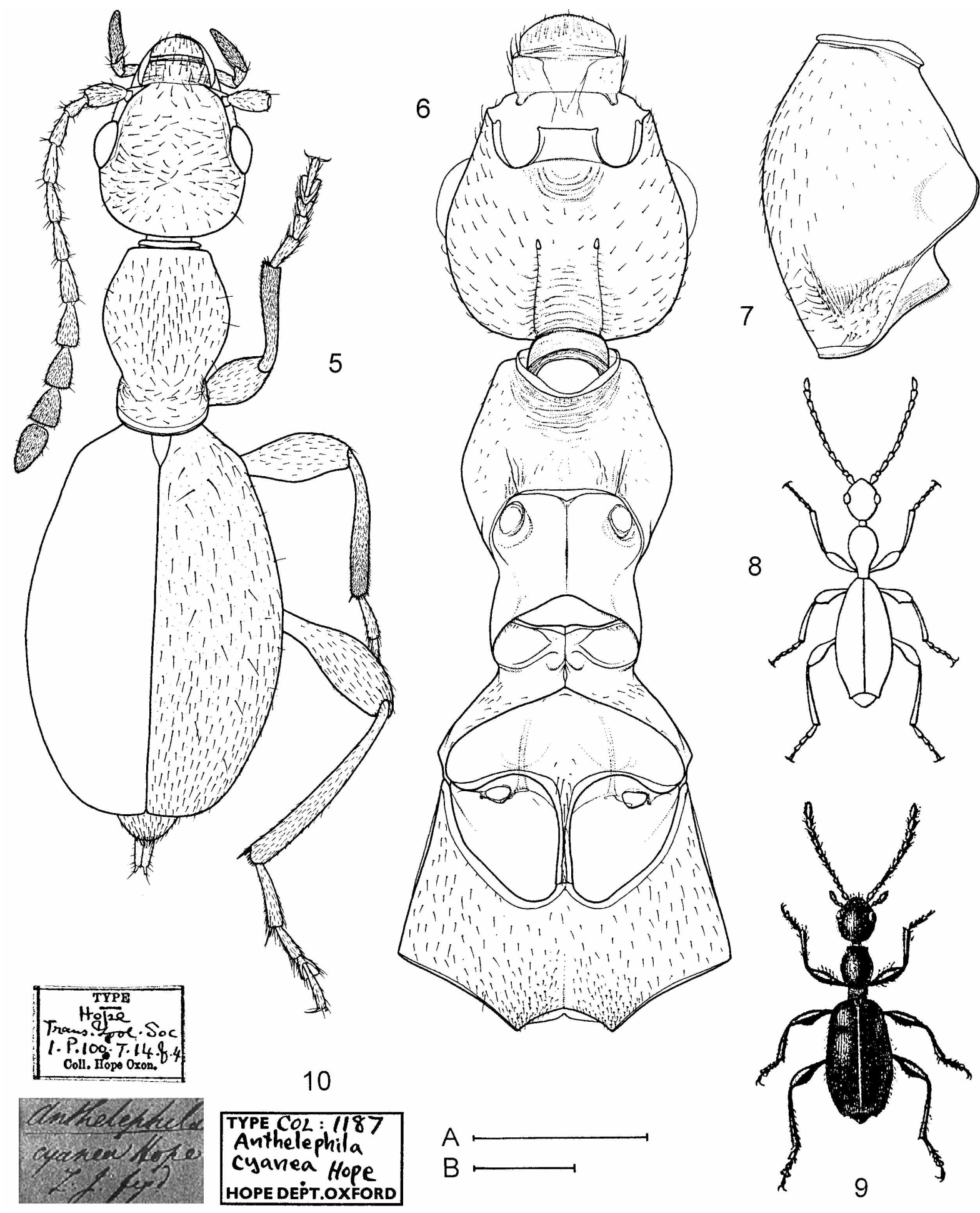

Figs 5-10. Anthelephila cyanea (female). 5 - habitus, dorsal view; 6 - thorax with head, ventral view; 7 - prothorax, lateral view; 8 - habitus (after LaFerté-Sénectère, 1849c); 9 - habitus (after Hope, 1833); 10 - the original labels of the Lectotype. Scale bars $(0.5$ mm): A - Figs 6, 7; B - Fig. 5.

femora moderately dilated on inner side proximally; protibiae with small, blunt, dent-like protrusion in distal half. Femora finely and comparatively sparsely setose, setae appressed to subdecumbent; tibiae (especially pro- and mesotibiae) distinctly more densely setose than femora; terminal margins of tibiae (especially metatibiae) with fringe of stiff, pointed, black setae laterally; tarsi with numerous longer, black bristle-like setae.
Male abdomen. Sternum VII (Fig. 23) with posterior margin shallowly emarginate medially and with short and wide, apically rounded process projecting from dorsal side of sternum closely before posterior margin; margins of median process bearing numerous long and stiff setae. Tergum VII (Fig. 24) simply and somewhat widely rounded posteriorly, with a pair of transverse, densely spinulose patches near base. Sternite VIII (Figs 25-27) 


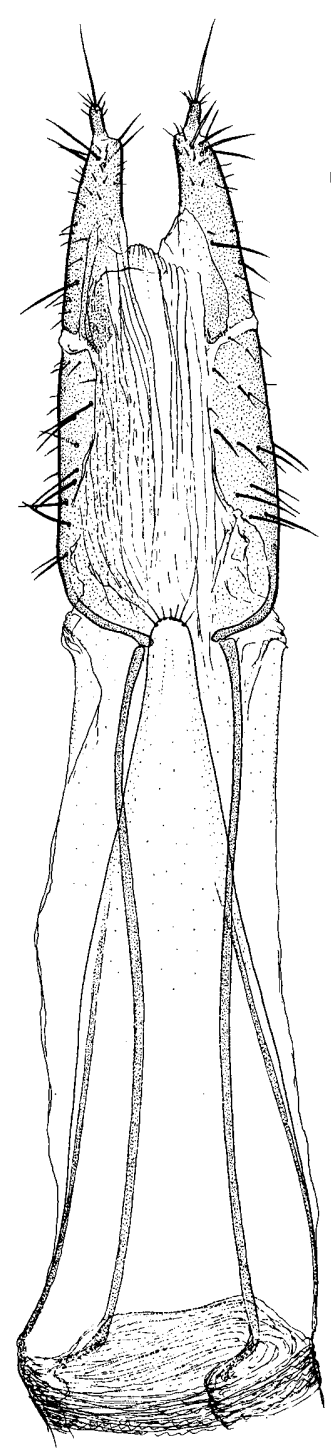

19
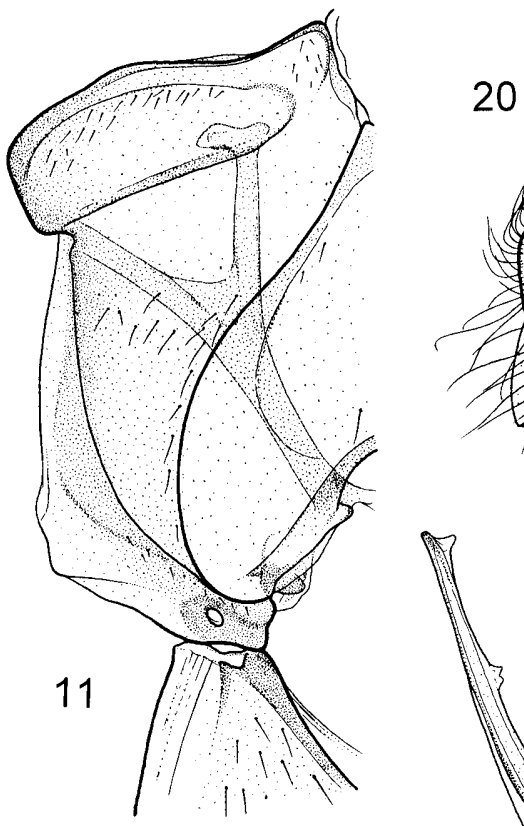

20
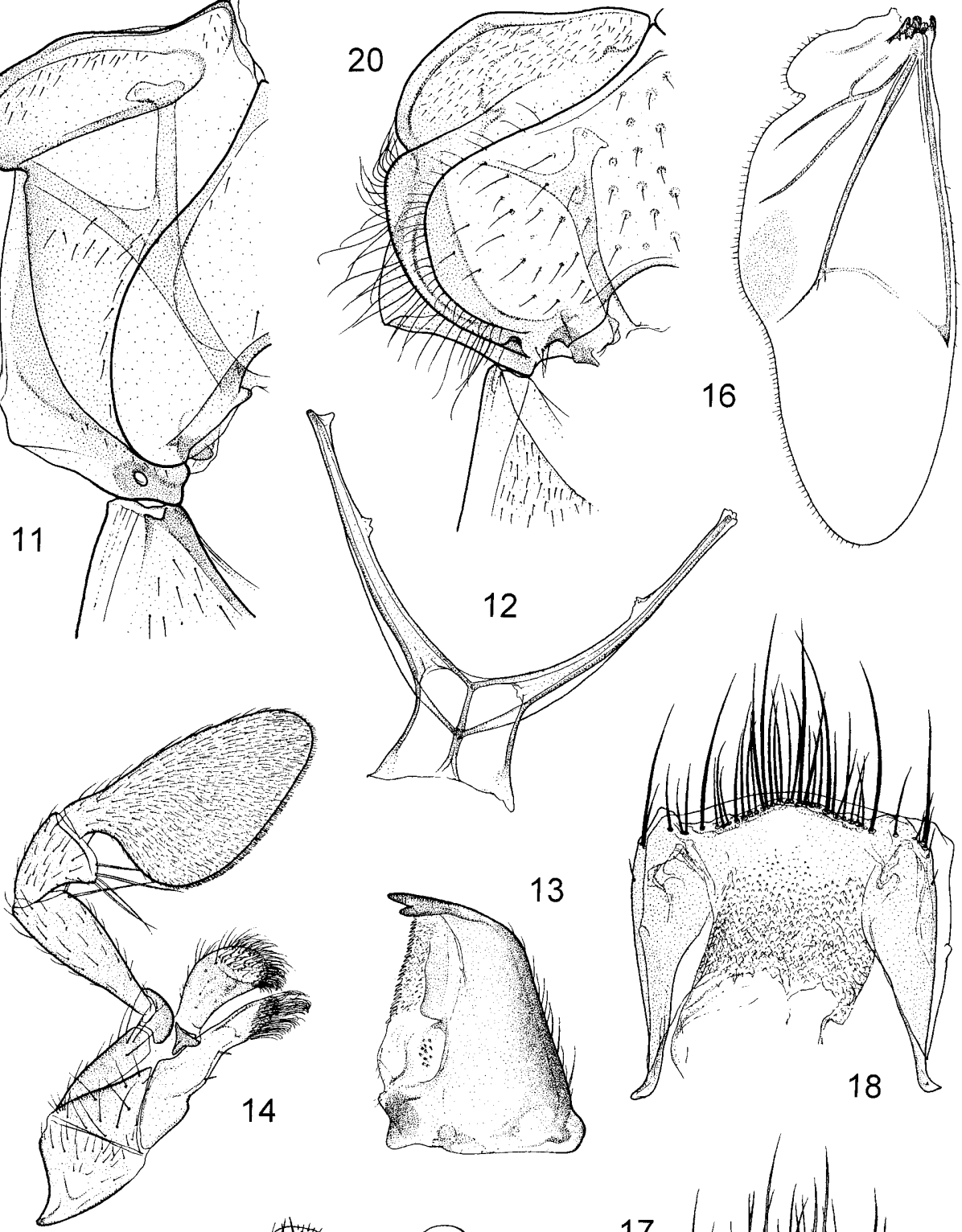

16
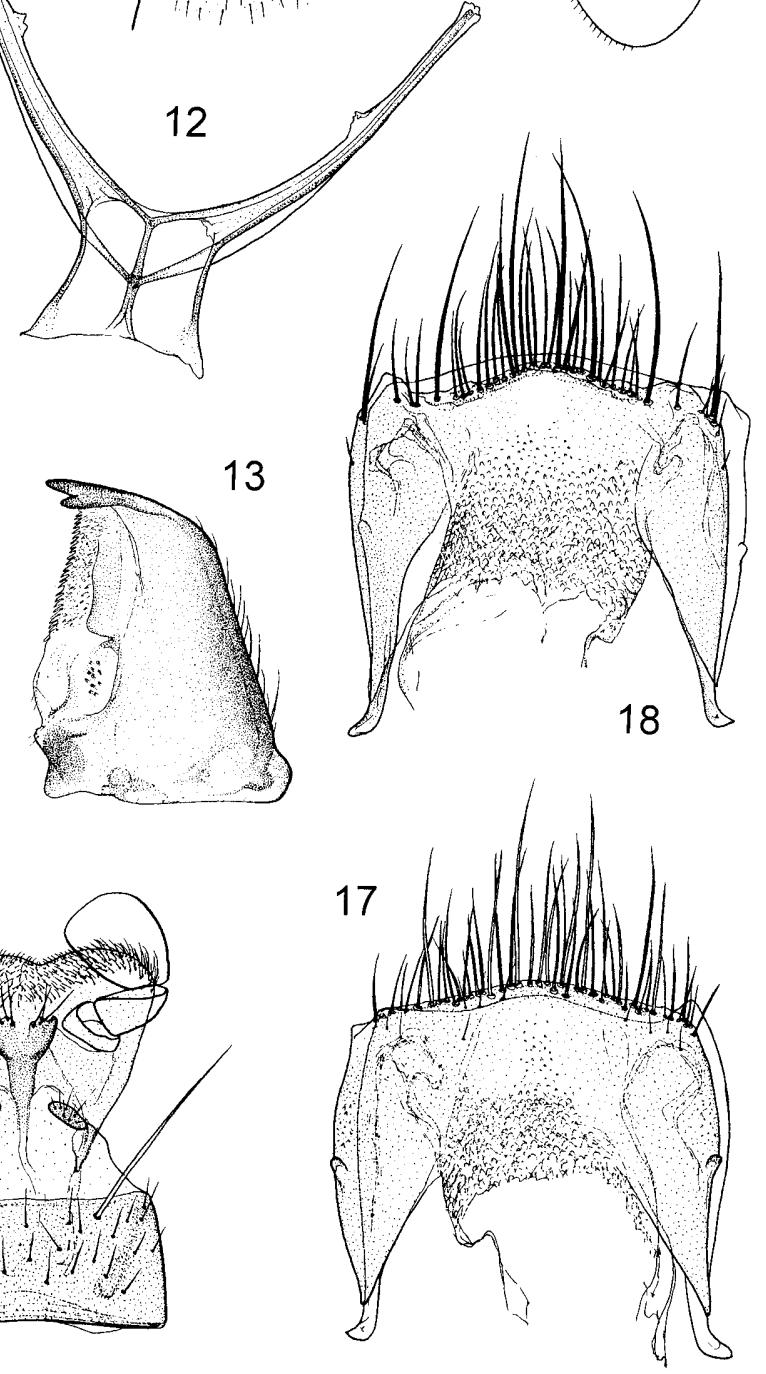

Figs 11-20. 11-19. Anthelephila cyanea (specimen from Greyton). 11 - mesothorax, ventro-lateral view; 12 - metendosternite; 13 - mandible, ventral view; 14 - maxilla; 15 - labium; 16 - membranous wing; 17 - female abdominal segment VIII, ventral view; 18 - the same, dorsal view; 19 - female ovipositor. 20 - Stricticomus transversalis (Villa \& Villa, 1833), mesothorax, ventro-lateral view. Scale bars (0.5 mm): A - Fig. 12; B - Fig. 16. (0.1 mm): C - Fig. 15; D - Fig. 19; E - Figs 11, 13, 14, 17, $18,20$.

clearly differentiated into five sclerites: paired prongs slim, moderately divergent distally, with three longitudinal, rather densely setose edges on medial and ventral side, each prong armed apically with three more sclero- tized and somewhat pointed projections and with two membranous lobes; median sclerite rather wide, transverse, with posterior margin straight, slightly emarginate medially; paired latero-basal sclerites medium-sized, 


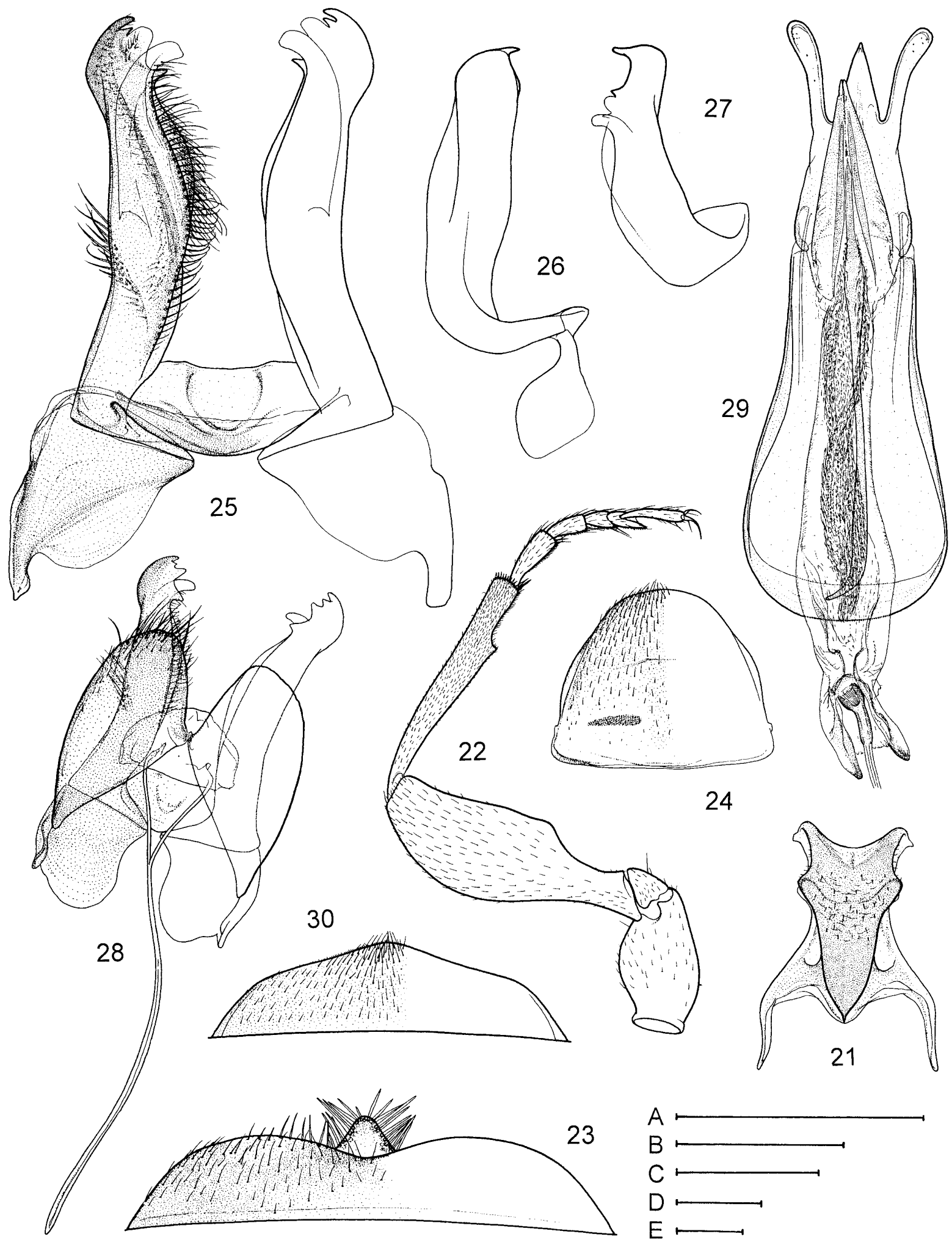

Figs 21-30. Anthelephila cyanea (specimen from Greyton). 21 - mesoscutellum, dorsal view; 22 - male front leg; 23 - male sternum VII, ventral view; 24 - male tergum VII, dorsal view; 25 - male sternite VIII, dorsal view; 26 - the same (outline), lateral view; 27 - prong of male sternite VIII (outline), dorso-caudal view; 28 - male abdominal segments VIII-IX, dorsal view; 29 - male aedeagus, ventral view; 30 - female sternum VII, ventral view. Scale bars $(0.5 \mathrm{~mm})$ : A - Figs 28, 30; B - Fig. 22; C - Fig. 24. (0.1 $\mathrm{mm})$ : D - Figs 25, 29; E - Figs 21, 23, 26, 27.

moderately dilated on medial side. Tergite VIII (Fig. 28) composed of a pair of flattened sclerites narrowly con- nected medially, simply rounded and long setose posteriorly. 
Aedeagus (Fig. 29); tegmen with apical portion 0.7 times as long as basal-piece, rather distinctly trilobed apically, lateral lobes divergent, rounded and slightly enlarged apically, middle lobe bluntly pointed and moderately shorter than lateral lobes; median lobe of aedeagus terminating in a pair of small, membranous projections.

Female abdomen. Sternum VII (Fig. 30) simply shaped, with posterior margin at most slightly produced medially; tergum VII similar to that in male, but more narrowed posteriorly and with posterior margin more densely and longer setose medially; both sternite and tergite VIII (Figs 17, 18) conspicuously long and densely setose along posterior margin. Ovipositor (Fig. 19).

Distribution. Originally described from Australia ("Novâ Hollandiâ"), however occuring in Africa, and here very probably confined to the southern part of the Cape province of South Africa (see Remarks).

Type material examined. Anthelephila cyanea - Lectotype, female [herewith designated; mounted, together with the original triangular label, on rectangular label], labelled (Fig. 10): “TYPE Hope Trans. Zool. Soc. I. P. 100. T.14 f.4 Coll. Hope Oxon. [both printed and handwritten, in fine red frame] Anthelephila cyanea Hope Z. J. [reddish label, handwritten, the last word illegible - see figure] $\backslash$ TYPE Col : 1187 Anthelephila cyanea HOPE DEPT. OXFORD [both printed and handwritten, in black frame]" (OXUM). Paralectotypes (lacking original labels): 2 females, mounted in the same way as lectotype (OXUM, BMNH); 1 female, mounted on triangular label, lacking head, with mouthparts mounted on separated label (OXUM).

Notoxus caeruleus - Syntypes [both pinned]: 1 male: "Uppsala Univ. Zool. Mus. Thunbergsaml. nr. 6593 Antichus coeruleus Mus. Thunb. TYP" [red label, printed]"; 1 female: "Uppsala Univ. Zool. Mus. Thunbersaml. nr. 14621 Antichus coeruleus Cap. TYP" [red label, printed]" (both UZIU).

Other material examined. $7 \AA z, 8 \circ q$, RSA, SW Cape Prov., ca $100 \mathrm{~km} \mathrm{E}$ of Cape Town, Greyton env., 22.x.1999, M. Snížek lgt. (CKD); 9 ठ大 ò, 6 우, same data, except 18.i.2001 (CKD); 1 ðै, RSA, Cape Prov., Paarl, 16.xi.1949, Malkin lgt. (DSC); 1 o, 1 क, RSA, Cape Prov., Bains Kloof, W. Side CL978, 25.ii.1979, J. T. Polhemus lgt. (DSC); 1 ๙ै, RSA, Cape Prov., Devon V, Stellenbosch, 17.iv.1992, O’Brien \& Marshall lgt. (DSC); 2 q + , RSA, Cape Prov., $3 \mathrm{~km} \mathrm{~S}$ Scarborough, 19.iv.1992, O'Brien \& Marshall lgt. (DSC); 2 o $\delta, 2$ 우, RSA, Cape Prov., Bellevue, 17.iv.1992, O'Brien \& Marshall lgt. (DSC); 4 oे के, RSA, Cape Prov., Cape Town, 15.v.1914 (DSC); 1 § , 1 q, "AF. Australe LE CAP \Formicomus cyaneus", bearing determination label "Formicomus caeruleus" by J. C. van Hille (DSC); 3 ơ ơ, RSA, Cape Prov., Mossel bay, Oudtshoorn, Palmiet riv., 24.ix.1953, Hille lgt. (DSC); 1 \&, RSA,

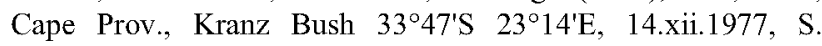
Endrödi lgt. (CUP); 1 $\delta$, RSA, Cape Prov., Constantia, 29.ix.1984, Evers lgt. (CUP); 1 z, 6 웅, RSA, Cape Prov., Franschhoek, 2-4.x.1991, K. Spornraft lgt. (CUP); 2 f d , 3 우, RSA, Cape Prov., Wellington, 8.x.1991, K. Spornraft lgt. (CUP).

Differential diagnosis. Anthelephila cyanea may be easily distinguished by the conspicuous metallic blue reflection of elytra, the angulately shaped anterior portion of the pronotum, double elytral punctation, modified mesosternum, and by the male characters.
Remarks. Anthelephila cyanea was described from Australia and never subsequently recorded until now. Having examined the type material, I found this species quite dissimilar to all its Australian congeners, placed in the here synonymized genus Formicomus, and identical in all characters with $F$. caeruleus (Thunberg, 1787) from southern Africa. Although there are examples of close relationships between the faunas of Australia and southern Africa (see Endrödi-Younga, 1978), Anthelephila does not seem to present this situation. Based on my studies, it appears to be rather derived genus, whose members colonized Australia from the Oriental region (see Distribution of the genus above). For these reasons, I believe that either the type locality of A. cyanea is erroneous, or the respective specimens were introduced to Australia.

Originally, Formicomus caeruleus was described by Thunberg (1787) in the genus Notoxus Geoffroy, 1762. Later, the species was listed under Anthicus by Dejean (1837), and then transferred to Formicomus by LaFertéSénectère $(1849 b, c)$. The examined syntypes are identical in all characters, including morphology of the prongs of male sternite VIII (their apical portion is exposed in the male specimen) with the types and the specimens additionally examined of Anthelephila cyanea. Consequently, $F$. caeruleus is regarded as junior synonym of the latter species.

Considering the records of herein synonymized $F$. caeruleus from South Africa (Hille, 1950, 1961; Uhmann, 1981, 1983b, 1984; Chandler \& Uhmann, 1984; Telnov 1998c), Namibia (Uhmann, 1985b, 1987b, 1995; Telnov 1998c), Botswana (Hille, 1986) and Angola (Hille, 1961), A. cyanea may appear like rather widespread species. However, I found the specimens originating from localities in the northern part of its range to be different from the typical $A$. cyanea in the more elongate elytra, regularly rounded, semicircular base of head, less enlarged distal antennomeres, moderately convex mesosternum (lacking paired impressions!) and in morphological details of the prongs of sternite VIII (especially of their apical portion); the male sternite VIII of $F$. caeruleus figured by Hille (1950) shows similar differences. As solution of this problem was beyond the scope of the present paper, no attempt was made to continue with examination of additional specimens from different regions. Specimens of the questionable "northern form" were examined from the following localities (CKD, CUP, DSC): South Africa: Bloemfontein, Cape Town-Kloof Nek, Gross Barmen Resort, Kamieskroon, Kuruman, Vioolsdrif, Winburg; Namibia: Noordoewer, Okahandja, Lüderitz, Warmbad, Windhoek.

ACKNOWLEDGEMENTS. I am very grateful to M. Eriksson (UZIU), B. Jaeger (MNHB), D.J. Mann (OXUM), D.S. Chandler (Durham), and G. Uhmann (Pressath) for the loan of specimens in their care. Furthermore, kind assistance of the following friends and colleagues is gratefully acknowledged: D. Telnov (Riga) first loaned the types of Anthelephila cyanea, but left the redescription of the species to the author; S. Bečvár (Institute of Entomology, Čské Budějovice) provided the SEM photographs; D.S. Chandler (University of New Hampshire, Durham) 
sent copies of some literature and valuable comments on the manuscript; J. Jelínek and V. Švihla (National Museum, Prague), D.S. Boukal (Institute of Entomology, České Budějovice), D.J. Mann (OXUM), M. Barelay (BMNH) and B. Jaeger (MNHB) were all helpful with advice and/or information on various subjects.

\section{REFERENCES}

Bonadona P. 1958: Insectes Coléoptères Anthicidae. Faune de Madagascar 6. L Institut de Recherche Scientifique, Tananarive-Tsimbazaza, $157 \mathrm{pp}$.

Bonadona P. 1974: La classification des Anthicidae de la faune de France (Coleoptera). L' Entomologiste 30: 101-111.

Bonadona P. 1978: Coléoptères Anthicidae du P.I.M.E. Entomological Museum de Detroit. Boll. Soc. Entomol. Ital. 110: $72-77$.

Bonadona P. 1982: Monographie du genre Phalanthias Heberdey (Coleoptera: Anthicidae). Rev. Suisse Zool. 89: $55-67$.

Bonadona P. 1984: Anthicides nouveaux ou peu connus d'Afrique Noire (Coleoptera: Anthicidae). Rev. Zool. Afr. 98 : 469-504.

Bonadona P. 1989: Anthicidae (Coleoptera) nouveaux des collections du Muséum d' histoire naturelle de Genève. Rev. Suisse Zool. 96: 253-276.

Bucciarelli I. 1980: Coleoptera: Anthicidae. Fauna d' Italia 17 Calderini, Bologna, 240 pp.

Chandler D.S. 2000: Publication Dates of Papers on the Anthicidae (Coleoptera) by the Marquis F. T. de LaFerté-Sénectère. Trans. Am. Entomol. Soc. 125: 433-439.

Chandler D.S. \& Uhmann G. 1984: New Records and a New Species of Anthicidae from Afrika (Coleoptera). Entomofauna, Z. Entomol. 5: 137-142.

Dejean P.F. 1837: Catalogue des Coléoptères de la Collection de M. Le Comte Dejean. Méquignon-Marvis Père et Fils, Paris, xiv $+503 \mathrm{pp}$.

ENDRÖDI-YounGA S. 1978: Coleoptera. In: Werger M.J.A. (ed.): Biogeography and Ecology of Southern Africa. Junk, The Hague, pp. 799-821.

FABRICIUS J.C. 1801: Systema Eleutheratorum Secundum Ordines, Genera, Species Adiectis Synonymis, Locis, Observationibus, Descriptionibus. Tomus 1. Impensis Bibliopolii Academici Novi, Kiliae, xxiv $+506 \mathrm{pp}$.

HeMP C. 1994: Anthiciden und Cantharidin. Ein Beitrag zur Chemischen Ökologie, Bionomie und Phylogenie der Ameisenkäfer (Coleoptera: Anthicidae). Dissertation, Universität Bayreuth, $131 \mathrm{pp}$.

Hemp C., Dettner K., Uhmann G. \& Hemp A. 1997: A contribution to the biology of the African canthariphilous anthicids Formicomus rubricollis LaFerté, 1848 and F. gestroi Pic, 1894. Mitt. Mïnch. Entomol. Ges. 87: 81-96.

Hemp C. \& Dettner K. 1997: Morphology and chemistry of Mesothoracic Glands in Anthicid Beetles (Coleoptera: Anthicidae). Entomol. Gener. 22: 97-108.

Hemp C. \& Dettner K. 2001: Compilation of canthariphilous insects. Beitr. Entomol. 51: 231-245.

HILle VAN J.C. 1950: Note on Formicomus caeruleus Thunb. with description of two new African Species (Anthicidae, Coleoptera Heteromera). J. Entomol. Soc. Sth. Afr. 13: 68-72.

Hirle van J.C. 1953: Note on Formicomus rufescens Pér. (Coleoptera: Anthicidae) and revision of the species of Formicomus with red prothorax in South Africa. Proc. R. Entomol. Soc. Lond. (Series B) 22: 9-14.
Hille van J.C. 1961: Chapter III. Coleoptera: Anthicidae. In: Hanström B., Brinck P. \& Rudebeck G. (eds): South African Animal Life 8. Almqvist \& Wiksells, Uppsala, pp. 217-258.

Hille van J.C. 1986: Anthicidae (Coleoptera heteromera) collected in Botswana, 1982-83. Botswana Notes and Records 17: $149-162$.

Hingston R.W.G. 1925: The Cremastogaster Ant. J. Bomb. Nat. Hist. Soc. 30: $541-550,1 \mathrm{pl}$.

Hope F.W. 1833: On the Characters of Several New Genera and Species of Coleopterous Insects. Proc. Zool. Soc. Lond. 1: 61-63.

Hope F.W. 1834: XI. Characters and Descriptions of several New Genera and Species of Coleopterous Insects. Trans. Zool. Soc. Lond. 1: 91-112, pls. xiii-xvi.

HOPE F.W. 1840: The Coleopterist's Manual, Part the Third, Containing Various Families, Genera, and Species, of Beetles, Recorded by Linneus and Fabricius. Also, Descriptions of newly Discovered and Unpublished Insects. J.C. Bridgewater, London, 191 pp. +3 pls.

ICZN 1999: International Code of Zoological Nomenclature, Fourth Edition. The International Trust for Zoological Nomenclature, London, xviii $+306 \mathrm{pp}$.

Kefval Z. 2000: Revisional notes on Oriental Formicomus LaFerté-Sénectère (Coleoptera: Anthicidae) 2. Himalayan species related to F. lagenicollis Fairmaire, 1894. Acta Mus. Moraviae, Sci. Biol. 85: 73-111.

KING R.L. 1869: Description of the Anthicides of Australia. Trans. Entomol. Soc. N. S. W 2: 1-24

Kolenati F.A. 1846: Meletemata Entomologica. Fasc. III. Brachelytra Caucasi cum Distributione Geographica Adnexis Pselaphinis, Scydmaenis, Notoxibus et Xylophagis. Petropoli, 44 pp., 5 pls.

KREKICH-STRASSOLDO VON H. 1925: Anthicidae of the Philippines I. Philipp. J. Sci. 27: 515-535, 3 pls.

KREKICH-STRASSOLDO VON H. 1928: Beiträge zur Kenntnis indischer Anthiciden. Arch. Naturgesch. A 92: 67-105.

Krekich-Strassoldo von H. 1929: Die Anthiciden der Philippinen, II. Philipp. J. Sci. 40: 453-483, 2 pls.

KREKICH-STRASSOLdo von H. 1931: Beiträge zur Kenntnis indischer Anthiciden II. Folia Zool. Hydrobiol. 3: 1-41, 3 pls.

LACORDARE T. 1859: Histoire Naturelle des Insectes. Genera des Coléoptères ou Exposé Méthodique et Critique de Tous les Genres Proposés Jusqu'ici Dans cet Ordre dInsectes. Tome 5, partie 2. Roret, Paris, pp. 401-750.

LAFER G.S. 1996: 101. Fam. Anthicidae. In: Ler P.A. (ed.): $A$ Key to the Insects of the Far East of the USSSR in Six Volumes. Vol. 3. Coleoptera or Beetles. Part 1. Dalnauka, Vladivostok, pp. 26-45. [in Russian]

LAFerté-SÉNECTĖRE de M.F. 1849a: Anthelephilus. In: GuérinMéneville F.-E. (ed.): Species et Iconographie Générique des Animaux Articulés ou Representation des Genres, avec leur Description et Celle de Toutes les Espèces de Cette Grande Division du Règne Animal. Première Partie: Insectes Coléoptères. Livraison 6, No. 24. Fain et Thunot, Paris, 5 pp., $1 \mathrm{pl}$.

LaFerté-SÉNeCtère de M.F. 1849b: Formicomus. In: GuérinMéneville F.-E. (ed.): Species et Iconographie ... Première Partie: Insectes Coléoptères. Livraison 7, No. 25. Fain et Thunot, Paris, 25 pp., 1 pl.

LaFerté-SéNeCtère De M.F. 1849c: Monographie des Anthicus et Genres Voisins. Coléoptères Hétéromères de la Tribu des Trachélides. Sapia, Paris, 340 pp.

MANNERHEIM M. 1846: Revue critique de quelques ouvrages récents de M. Victor de Motschoulsky. Bull. Soc. Imp. Nat. Moscow 19: 194-254. 
Motschoulsky De M.V. 1845a: Remarques sur la collection de coléoptères Russes. Bull. Soc. Imp. Nat. Moscow 18: 3-127, pls. 1-3.

Motschoulsky De M.V. 1845b: Corrections a faire dans l'article intitulé: "Remarques sur la Collection de Coléoptères russes de Victor de Motschoulsky." Bulletin No. 1 1845. Bull. Soc. Imp. Nat. Moscow 18: unnumbered page at end of issue.

MotsChoursKY DE M.V. 1849: Coléoptères reçus d'un voyage de M. Handschuh dans le midi de l'Espagne enumeres et suivis de notes. Bull. Soc. Imp. Nat. Moscow 22: 52-163.

Neave S.A. 1939: Nomenclator Zoologicus. A list of Names of Genera and Subgenera in Zoology from the Tenth Edition of Linnaeus 1758 to the end of 1935. Zoological Society of London, 4 vols.

NomuRA S. 1962: The Anthicid-Beetles from the Loochoo Islands. Entomol. Rev. Japan 14: 1-7.

PIC M. 1899: Hylophilidae, Anthicidae et Pedilidae de L' Ille de Sumatra. Ann. Soc. Entomol. Fr. 68: 754-760.

PIC M. 1901: Deuxième supplément a ma liste de Anthicides (1897-1900). Ann. Soc. Entomol. Belg. 45: 248-257.

PIC M. 1911: Anthicidae. In: Junk W. \& Schenkling S. (eds) Coleopterorum Catalogus 17, pars 36. W. Junk, Berlin, pp. $1-102$.

PIC M. 1956: Contribution á létude de la faune entomologique du Ruanda-Urundi (Mission P. Basilewsky 1953). XII. Coleoptera Rhipiphoridae, Oedemeridae, Scraptiidae, Pedilidae, Aderidae, Anthicidae, Dermestidae, Byrrhidae, Anobiidae, Ptinidae, Cleridae, Lymexylonidae et Helodidae. Annls. Mus. R. Congo Belge Tervuren (Sci. Zool.) 36: 125-135.

Rossi P. 1790: Fauna Etrusca Sistens Insecta Quae in Provinciis Florentina et Pisana Praesertim Collegit Petrus Rossius in Regio Pisano Athenaeo. Tomus Primus. Typis Thomae Masi \& Sociorum, Liburni, xxii 272.

SAKAI M. 1989: Anthicidae. In: Hirashima Y. (ed.): A Check List of Japanese Insects, Vol. 1. Kyushu University, Fukuoka, $\mathrm{xi}+1-540 \mathrm{pp}$.

SAUNDERS W.W. 1834: On the Habits of some Indian Insects Trans. Entomol. Soc. Lond. 1: 60-66.

SHerborN C.D. 1922-1933: Index Animalium Sive Index Nominum Quae ab A.D. MDCCLVIII Generibus et Speciebus Animalium Imposita Sunt, Sectio Secunda a Kalendis Ianuariis MDCCCI Usque ad Finem Ecembris MDCCCL. Cambridge University Press, London, 9 vols.

Scнüтz C. 1989: Die Mesothorakaldrüse der Anthicidae (Coleoptera: Heteromera). Morphologie, Chemie und Phylogenetische Bedeutung. Diplomarbeit, Universität Bayreuth, 87 pp.

Telnov D. 1997: Anthicidae aus Nordvietnam (Insecta: Coleoptera). Mitt. Int. Entomol. Ver. Frankf. 22: 59-65.

Telnov D. 1998a: Anthicidae aus Nordvietnam II (Insecta: Coleoptera). Mitt. Int. Entomol. Ver. Frankf. 23: 85-93.

Telnov D. 1998b: Anthicidae (Coleoptera) der Sammlung Sergej Kurbatov, mit Beschreibung von sechs neuen Arten aus der Orientalis. Bull. Ann. Soc. R. Belge Entomol. 134: $81-100$.

Telnov D. 1998c: Afrikanische Anthicidae (Coleoptera) aus der Sammlung der Naturkundemuseums Erfurt. Veröff. Naturkundemus. Erfurt 17: 59-70.

Telnov D. 1999: Weitere Anthicidae verschiedener Regionen aus dem Zoologischen Museum Kopenhagen (Insecta: Coleoptera). Bull. Soc. R. Belge Entomol. 135: 72-81.

Thunberg C.P. 1787: Donation. Thunbergianae 1785. Continuat II. (pp. 43-58). In: D.D. Museum Naturalium Academiae Upsaliensis. Pars 1-8 (1787-1789). Johann Edman, Upsaliae, 106 pp., 1 pls.
Truqu E. 1855: Anthicini insulae Cypri et Syriae. Mem. Accad. Sci. Torino 16: 339-371, $1 \mathrm{pl}$.

Uhmann G. 1976: Die Gattungen der Anthicidae und Ihre systematische Anordnung. Entomol. Bl. 72: 166-182.

Uhmans G. 1978: Die Gattungen der Anthicidae und ihre systematische Anordnung. Teil 2. Die systematische Anordnung. Entomol. Bl. 74: 75-80.

Uhmann G. 1980: Anthicidae aus Nepal, Kashmir und Ladakh. Results of Himalaya Expeditions of L. Martens, No. 62. Senckenberg. Biol. 60: 163-169.

Uhmann G. 1981: Anthiciden (Coleoptera) aus Africa, Teil 2. Annls Hist.-Natur. Mus. Nat. Hung. 73: 187-196.

Ummann G. 1983a: Anthiciden der orientalischen Region (Coleoptera, Anthicidae). Annls Hist-Natur. Mus. Nat. Hung. 75: 185-206.

Uhmann G. 1983b: Anthiciden aus Afrika, Nachtrag (Coleoptera). Folia Entomol. Hung. 44: 197-200.

Unmann G. 1984: Die Anthicidae der Sammlung der Universität Pretoria (Coleoptera, Anthicidae). Entomofauna, Z. Entomol. 5: 235-241.

Ummann G. 1985a: Anthicidae (Coleoptera) from the Institute of Zoology, Warsaw. Annls Zool., Warsz. 39: 119-129.

Ummann G. 1985b: Anthiciden aus Namibia (Coleoptera: Anthicidae). Bonn. Zool. Beitr. 36: 177-183.

Uhmann G. 1986: Anthicidae aus Nepal, II. (Insecta: Coleptera). Senckenberg. Biol. 66: 305-310.

UHMANN G. 1987a: Anthiciden der orientalischen Region aus dem Museum in Genf (Coleoptera: Anthicidae). Rev. Suisse Zool. 94: 687-701.

UhMANN G. 1987b: Anthiciden aus Namibia II. (Coleoptera: Anthicidae). Bonn. Zool. Beitr. 38: 59-64.

Uhmann G. 1988: Die Anthicidae der Sammlung Johann Klapperich (Coleoptera). Bonn. Zool. Beitr. 39: 395-407.

UHManN G. 1989: Anthicidae (Coleoptera der orientalischen Region aus dem Naturhistorischen Museum in Genf, II. Rev. Suisse Zool. 96: 243-252.

Uhmann G. 1990a: Anthicidae aus Nepal III. Results of the Himalaya Expeditions of J. Martens. Entomofauna, Z. Entomol. 11: 333-347.

Uhmann G. 1990b: Weitere Anthiciden verschiedener Regionen aus dem Museum in Genf (Coleoptera: Anthicidae). Rev. Suisse Zool. 97: 139-151.

UhmanN G. 1990c: Anthiciden aus dem Naturhistorischen Museum in Genf II. (Coleoptera: Anthicidae). Rev. Suisse Zool. 97: 887-893.

UHMANN G. 1990d: Anthicidae aus dem Oberösterreichischen Landesmuseum in Linz (Coleoptera: Anthicidae). Linzer Biol. Beitr. 22: 577-595.

Uhmann G. 1994a: Die von Rudolf Schuh in Asien gefundenen Anthiciden (Insecta: Coleoptera: Anthicidae). Entomofauna, Z. Entomol. 15: 405-416.

UHMANN G. 1994b: Südostasiatische Anthiciden aus dem Naturhistorischen Museum in Genf, 4 (Coleoptera: Anthicidae). Rev. Suisse Zool. 101: 655-676.

UHMAnN G. 1995: Die Anthicidae der ersten entomologischen Afrika-Expedition des Museums für Naturkunde Berlin 1992 nach Namibia und weitere Nachweise aus Namibia und Südafrika. The Anthicidae of the First Entomological Expedition of the Museum of Natural History Berlin to Namibia in 1992 and other records from Namibia and South Africa. Mitt. Zool. Mus. Berl. 71: 341-352.

UHManN G. 1996: Anthiciden aus dem Naturhistorischen Museum in Wien (Coleoptera: Anthicidae). Entomol. Bl. 92 : 19-36. 
Wasmann S.J. 1898: Einige neue myrmecophile Anthiciden aus Indien. Verh. Zool. Bot. Ges. Wien 48: 482-484.

WERNER F.G. 1966: A New Genus of Anthicidae (Coleoptera) from Chile. Ann. Entomol. Soc. Amer. 59: 222-226.

WERNER F.G. 1970: A Revision of Acanthinus (Coleoptera Anthicidae). X. Albicinctus-Group and Conclusions. Ann. Entomol. Soc. Amer. 63: 859-876.
WERNER F.G. 1974: A review of the chilean Anthicidae (Coleoptera). Rev. Chilena Entomol. 8: 27-34.

Werner F.G. \& Chandler D.S. 1995: Anthicidae (Insecta: Coleoptera). Fauna of New Zealand 34. Manaaki Whenua Press, Lincoln, $59 \mathrm{pp}$.

ZIMSEN E. 1964: The Type Material of J.C. Fabricius. Munksgaard, Copenhagen, $656 \mathrm{pp}$.

Received November 7, 2002; revised January 16, 2003; accepted March 4, 2003 